\title{
The organization and financing of cervical cancer prevention carried out by midwives in primary health care
}

\author{
Karolina Sobczyk ${ }^{1}$, Joanna Woźniak-Holecka ${ }^{1}$, Tomasz Holecki ${ }^{1}$, Dorota Szałabska² \\ ${ }^{1}$ Department of Health Economics and Management, School of Public Health in Bytom, \\ Medical University of Silesia in Katowice, Poland \\ ${ }^{2} \mathrm{School}$ of Public Health in Bytom, Medical University of Silesia in Katowice, Poland
}

\begin{abstract}
Objective: The main objective of the project was the evaluation of the organizational and financial aspects of midwives in primary health care (PHC), functioning under The Population Program for the Early Detection of Cervical Cancer two years after the implementation of new law regulations, which enable this occupational group to collect cytological material for screening.

Material and methods: Under this project, the data of the Program's Coordinating Centre, affecting midwives' postgraduate education in the field of pap smear tests, was taken into analysis. Furthermore, The National Health Fund (NFZ) reports on contracts entered in the field of the discussed topics, taking into consideration the value of health services performed within the Program in respect of ambulatory care and primary care units.

Results: NFZ concluded contracts for the provision of PHC service with 6124 service providers in 2016, including the contracts in the field of providing health services under the cervical cancer prevention program by $\mathrm{PHC}$ midwifes, which were entered into by 358 institutions (5.85\%). The value of the basic services under the Program, carried out under NFZ contracts in 2014, amounted to approx. PLN 12.3 million, while the value of services performed by PHC midwives represented only $0.38 \%$ of this sum.

Conclusions: The introduction of legislative changes, allowing PHC midwives to collect cytological material for screening, did not cause, in the period of the observation on a national scale, the expected growth of availability of basic stage services within the cervical cancer prevention program.
\end{abstract}

Key words: cervical cancer, prevention, primary health care midwives, health care economics and organization

\section{INTRODUCTION}

In the statistics concerning both morbidity and mortality of women around the world, cervical cancer (CC) was ranked fourth, right after breast cancer, colon cancer and lung cancer [1]. Although a significant progress in limiting mortality caused by CC around the world was recorded, the mortality rate for 2012 in Poland was on a high level of 7.4/100 000 women. It significantly differs from the European Union average (3.7/100 000 women). The morbidity rate for the year 2012 in Poland amounts to $15.3 / 100000$, whereas the average in the European Union is
11.3/100 000. Every year, approximately 3,000 new CC cases are diagnosed in Polish women, 1,700 of which are fatal [1, 2]. Five-year morbidity rate among Polish women reaches the value of 10,900 [3].

Highly inconvenient situation concerning epidemiologic indicators in Poland resulted in population screenings, which started in 2007 as the basis for the secondary CC preventive care. Based on the Act dated 1 July 2005 on establishing the multi-year national cancer control program, the Population Program for the Early Detection of Cervical Cancer was established (later called The Program). 
The Program is associated with the Population Program for the Early Detection of Breast Cancer since 2011. Under the described program, pap smears are available for patients at the age of 25 to 59 , who had no diagnostics of this type performed within the last 3 years. In the case of women in the risk group, the diagnostics is performed every year [4, 5].

Up to 31 December 2013, the collecting of cytological material for screening was possible only under the specialized outpatient care (SOC), constituting the basic organizational pillar of the Program. New law regulations, introduced on 1 January 2014 allow for the collection of cytological material under the cervical cancer prevention program by PHC midwife (who had previously obtained the required qualifications in the field of collecting pap smears, for the needs of the Program). Both PHC and SOC midwives are required to pass the exam organized by the Coordinating Centre (COC), taken after 31 October 2010, or to complete the refresher course organized by $\mathrm{COC}$ or Provincial Coordinating Centre (PCOC). Moreover, a candidate for Program provider should have proper equipment and medical apparatus, among which the most essential is a disposable speculum, disposable wand allowing the collection of pap smear from the shield of the vaginal part and from the cervical canal at the same time, and also a gynecological chair [5].

The Program consists of three stages, in which the last two (diagnostics and deeper diagnostic) are performed under the contracts concluded with National Health Fund (NFZ) under preventive health programs [6]. The basic stage of the Program is implemented under the contracts entered into under SOC, and as it was mentioned above, since 2014 also under PHC [5]. The details concerning entering into basic stage contracts on health services execution by NFZ were stated in Table 1.

The main objective of the project was the evaluation of the organizational and financial aspects of midwives in primary care, functioning under the Population Program for the early detection of cervical cancer, two years after introducing new law regulations, which allow this occupational group to collect cytological material for screening.

\section{MATERIAL AND METHODS}

The project was implemented from 1 September 2015 to 15 February 2016. The first stage consisted in the analysis of legal acts allowing the collection of pap smear by PHC midwives within the Program. Subsequently, in the second stage, the data of the Program's Coordinating Centre, affecting midwives' postgraduate education in the field of collecting pap smears, was taken into analysis. The third stage, focuses on the National Health Fund's reports. The reports refer to contracts entered within the discussed topics and the data acquired from this subject, affecting the value of services performed under the Program by specialized outpatient care and primary care units. The results were compiled using Microsoft Office 2015 software.

\section{RESULTS}

According to the NFZ data for the year 2016, the contracts for providing the basic stage services under the Program were signed with 3195 providers. The number of providers has increased 400 , as compared to the previous years - 2828 providers in 2015 and 2834 in 2014. Among all contracts entered into in $2016,11.2 \%$ were signed with $\mathrm{PHC}$ providers, which indicates a growing tendency in this respect - in the previous year this value amounted to $7.8 \%$ (221), whereas in 2014 - 5.1\% (144). In general, the largest percentage of contracts entered with PHC in 2016 was recorded in the Śląskie (31.6\%), Pomorskie (12.4\%) and Mazowieckie (10.3\%) voivodeship. On the other hand, the lowest percentage was reported in Łódzkie (1.58\%) and Zachodniopomorskie (1.65\%) voivodeship. The details are presented in Table 2 and illustrated in Figures 1 and 2.

The National Health Fund concluded contracts for the provision of PHC services with 6124 providers in the year 2016 , including the contracts in the field of providing health services under the cervical cancer prevention program by a PHC midwife, which were entered by 358 institutions (5.85\%). In general, among all PHC institutions, the largest percentage share of service providers performing the health services concerned, under NFZ contract, was recorded in the Śląskie voivodeship (22.6\%), whereas the lowest percentage

Table 1. The execution of the basic stage of the Cervical Cancer Prevention Program in the framework of the contract with the National Health Fund [6]

\begin{tabular}{|l|l|l|}
\hline $\begin{array}{l}\text { Stage of the program } \\
\text { Type of service }\end{array}$ & Basic stage & Basic stage \\
\hline Name of the product & Specialized outpatient care & Primary health care \\
\hline Product's code & Collecting pap smear for screening & $\begin{array}{l}\text { PHC midwife services under the cervical cancer } \\
\text { prevention program }\end{array}$ \\
\hline Staff & 02.1450 .101 .02 & 01.0034 .101 .01 \\
\hline
\end{tabular}




\begin{tabular}{|c|c|c|c|c|c|c|c|c|c|c|}
\hline \multicolumn{2}{|c|}{ Year } & \multicolumn{3}{|c|}{2014} & \multicolumn{3}{|c|}{2015} & \multicolumn{3}{|c|}{2016} \\
\hline No. & NFZ district & SOC & PHC & $\%$ PHC & SOC & PHC & $\%$ PHC & SOC & PHC & $\%$ PHC \\
\hline 1 & Dolnośląski & 213 & 13 & $5.75 \%$ & 208 & 14 & $6.31 \%$ & 225 & 16 & $6.64 \%$ \\
\hline 2 & Kujawsko-pomorski & 205 & 8 & $3.76 \%$ & 195 & 15 & $7.14 \%$ & 209 & 15 & $6.70 \%$ \\
\hline 3 & Lubelski & 108 & 7 & $6.09 \%$ & 101 & 12 & $10.62 \%$ & 109 & 12 & $9.92 \%$ \\
\hline 4 & Lubuski & 45 & 1 & $2.17 \%$ & 44 & 4 & $8.33 \%$ & 57 & 4 & $6.56 \%$ \\
\hline 5 & Łódzki & 187 & 3 & $1.58 \%$ & 178 & 3 & $1.66 \%$ & 187 & 3 & $1.58 \%$ \\
\hline 6 & Małopolski & 200 & 8 & $3.85 \%$ & 200 & 9 & $4.31 \%$ & 210 & 12 & $5.41 \%$ \\
\hline 7 & Mazowiecki & 300 & 19 & $5.96 \%$ & 297 & 39 & $11.61 \%$ & 306 & 35 & $10.26 \%$ \\
\hline 8 & Opolski & 61 & 7 & $10.29 \%$ & 61 & 60 & $49.59 \%$ & 81 & 6 & $6.90 \%$ \\
\hline 9 & Podkarpacki & 118 & 6 & $4.84 \%$ & 117 & 5 & $4.10 \%$ & 140 & 6 & $4.11 \%$ \\
\hline 10 & Podlaski & 65 & 6 & $8.45 \%$ & 64 & 2 & $3.03 \%$ & 70 & 5 & $6.67 \%$ \\
\hline 11 & Pomorski & 135 & 18 & $11.76 \%$ & 132 & 20 & $13.16 \%$ & 155 & 22 & $12.43 \%$ \\
\hline 12 & Śląski & 446 & 13 & $2.83 \%$ & 424 & 15 & $3.42 \%$ & 446 & 206 & $31.60 \%$ \\
\hline 13 & Świętokrzyski & 125 & 2 & $1.57 \%$ & 120 & 4 & $3.23 \%$ & 129 & 4 & $3.01 \%$ \\
\hline 14 & Warmińsko-mazurski & 109 & 5 & $4.39 \%$ & 106 & 7 & $6.19 \%$ & 128 & 4 & $3.03 \%$ \\
\hline 15 & Wielkopolski & 246 & 23 & $8.55 \%$ & 239 & 10 & $4.02 \%$ & 266 & 6 & $2.21 \%$ \\
\hline 16 & Zachodniopomorski & 127 & 5 & $3.79 \%$ & 121 & 2 & $1.63 \%$ & 119 & 2 & $1.65 \%$ \\
\hline \multicolumn{2}{|c|}{ TOTAL } & 2690 & 144 & $5.08 \%$ & 2607 & 221 & $7.81 \%$ & 2837 & 358 & $11.21 \%$ \\
\hline
\end{tabular}

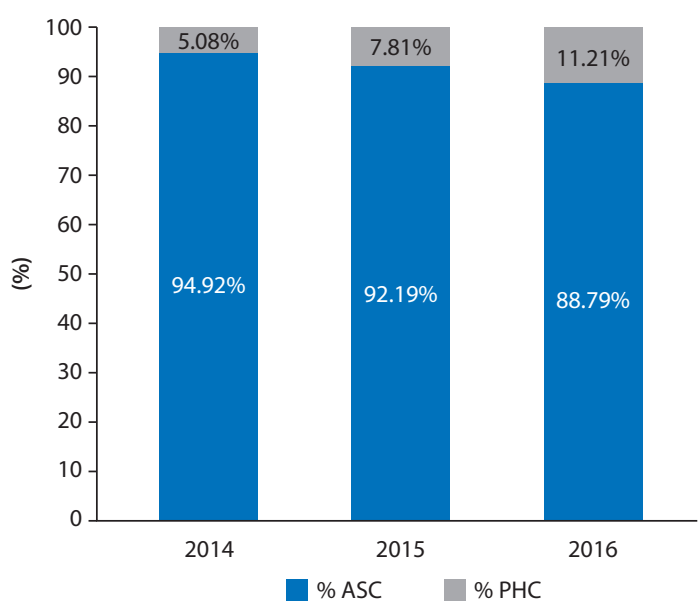

Figure 1. The percentage of primary health care service providers in realization of cervical cytology screening (source: ibidem)

share was recorded in Łódzkie, Zachodniopomorskie and Wielkopolskie (below 1\%) voivodeships. The detailed data is presented in Table 3.

The value of the basic stage services under the Program, realized under NFZ contract in the year 2014, was approximately PLN 12.3 million, while the amount of services performed by PHC midwives constituted only $0.38 \%$ of that sum. Out of all the contracts entered into in the period concerned, more than 700,000 pap smear tests were

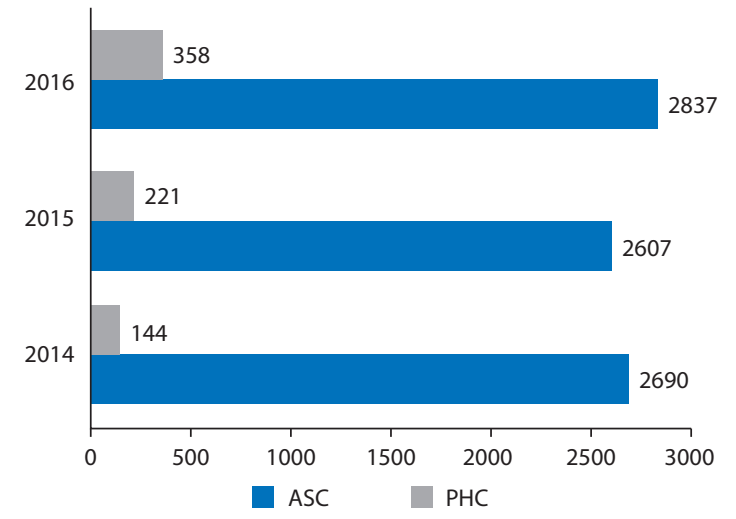

Figure 2. The number of service providers having contracts with the National Health Fund for the cervical cytology screening for years 2014-2016 in division into ambulatory specialized care and primary care (source: ibidem)

performed, among which only approximately 3,000 (0.42\%) were performed under PHC conditions (Table 4). The average value of a single service, performed under AOS, was PLN 17.55, and PLN 16.07 for PHC

According to $\mathrm{COC}$ data referring to midwives' postgraduate education in the year 2014, the course in the field of collecting pap smears was participated by 753 midwives, including 314 who worked in SOC (41.7\%) and 439 employed in PHC (58.3\%). The majority of participants came 


\begin{tabular}{|c|c|c|c|c|c|c|}
\hline \multirow{3}{*}{ No. } & \multirow{3}{*}{ NFZ district } & \multicolumn{4}{|c|}{$\begin{array}{l}\text { The contract for providing services, by a PHC midwife, } \\
\text { within the Cervical Cancer Prevention Program }\end{array}$} & \\
\hline & & \multicolumn{2}{|c|}{ Yes } & \multicolumn{2}{|c|}{ No } & \\
\hline & & Number & $\%$ & Number & $\%$ & \\
\hline 1 & Dolnośląski & 16 & $3.14 \%$ & 493 & $96.86 \%$ & 509 \\
\hline 2 & Kujawsko-pomorski & 15 & $4.57 \%$ & 313 & $95.43 \%$ & 328 \\
\hline 3 & Lubelski & 12 & $4.71 \%$ & 243 & $95.29 \%$ & 255 \\
\hline 4 & Lubuski & 4 & $2.26 \%$ & 173 & $97.74 \%$ & 177 \\
\hline 5 & Łódzki & 3 & $0.76 \%$ & 392 & $99.24 \%$ & 395 \\
\hline 6 & Małopolski & 12 & $2.84 \%$ & 410 & $97.16 \%$ & 422 \\
\hline 7 & Mazowiecki & 35 & $6.38 \%$ & 514 & $93.62 \%$ & 549 \\
\hline 8 & Opolski & 6 & $3.31 \%$ & 175 & $96.69 \%$ & 181 \\
\hline 9 & Podkarpacki & 6 & $1.71 \%$ & 344 & $98.29 \%$ & 350 \\
\hline 10 & Podlaski & 5 & $2.26 \%$ & 216 & $97.74 \%$ & 221 \\
\hline 11 & Pomorski & 22 & $7.17 \%$ & 285 & $92.83 \%$ & 307 \\
\hline 12 & Śląski & 206 & $22.56 \%$ & 707 & $77.44 \%$ & 913 \\
\hline 13 & Świętokrzyski & 4 & $1.49 \%$ & 264 & $98.51 \%$ & 268 \\
\hline 14 & Warmińsko-mazurski & 4 & $1.23 \%$ & 321 & $98.77 \%$ & 325 \\
\hline 15 & Wielkopolski & 6 & $0.90 \%$ & 663 & $99.10 \%$ & 669 \\
\hline 16 & Zachodniopomorski & 2 & $0.78 \%$ & 253 & $99.22 \%$ & 255 \\
\hline \multicolumn{2}{|c|}{ TOTAL } & 358 & $5.85 \%$ & 5766 & $94.15 \%$ & 6124 \\
\hline
\end{tabular}

from Lubelskie (133; 17.6\%) and Mazowieckie (100; 13.3\%) voivodeships. There were no midwives from Łódzkie, Lubuskie, Podlaskie, Warmińsko-Mazurskie voivodeships participating in the course. The details are presented in Table 5.

\section{DISCUSSION}

The aim of the described legislative changes was to increase the availability of services within the Program. According to sociological research, some women who do not undergo pap smear tests, encounter some bruising obstacles. The main originators of legislative changes assumed that if such diagnostics is performed by a woman, and this woman is a primary care midwife known to the patient for many years, it might significantly increase the reportability of medical examinations [7]. Insufficient reportability of women in the framework of cytological screenings and high costs of the implementation of the Program work as an impulse to improve the existing programs and search for new solutions in terms of CC preventive care. The low effectiveness of the Program is mostly caused by unequal access to preventive examinations in certain voivodeships and insufficient reportability of women from the target group [8]. With regard to the availability of cytological diagnostics under $\mathrm{PHC}$, regional inequalities have also been observed. The largest percentage share of PHC institutions, which provide the health services concerned, was recorded in the Śląskie voivodeship, with more than $22,5 \%$ of all clinics, followed by the Pomorskie (7.2\%) and Mazowieckie (6.4\%) voivodeships. Numerical data clearly indicates regional diversification in access to $\mathrm{PHC}$ basic services under the Program, including the fact of overstating the national data by the Śląskie voivodeship, according to which $5.8 \%$ of all clinics enter contracts for PHC midwife's services within the Program.

In Barnaś et al. research it is observed that the increase in the number of service providers, where pap smear tests can be performed, results in the larger number of examinations in particular years of the Program [9]. On the basis of NFZ data affecting the number of service providers actively participating in the Program, one cannot clearly conclude a growing tendency in this respect. For the year 2016, 2837 contracts have been signed, which constitutes an increase of more than 200 service providers, in comparison to the previous year (2607 contracts in 2015). It needs to be emphasized that in 2015 a loss of 83 providers was noted whereas 2690 entities entered into contracts in 2014. A growing tendency can be reported when analyzing the number of $\mathrm{PHC}$ service providers who are involved in the basic stage of the Program under NFZ contract. Since 2014, their number has grown 2.5 times, from 144 entities to 358 in 
Table 4. The number and value of services provided under the basic stage of the Cervical Cancer Prevention Program in 2014, broken down into specialized outpatient care and primary health care (source: ibidem)

\begin{tabular}{|c|c|c|c|c|c|c|c|c|}
\hline \multirow{2}{*}{ No. } & \multirow{2}{*}{ NFZ district } & \multicolumn{3}{|c|}{$\begin{array}{l}\text { The collection of pap smear for screening } \\
\text { (SOC) }\end{array}$} & \multicolumn{3}{|c|}{$\begin{array}{c}\text { PHC midwives' services within cervical cancer } \\
\text { prevention program }\end{array}$} & \multirow{2}{*}{ TOTAL } \\
\hline & & Number & $\%$ & $\begin{array}{l}\text { Value of } \\
\text { services }\end{array}$ & Number & $\%$ & $\begin{array}{l}\text { Value of } \\
\text { services }\end{array}$ & \\
\hline 1 & Dolnośląski & 50063 & $99.27 \%$ & 918156.14 & 367 & $0.73 \%$ & 5888.00 & 50430 \\
\hline 2 & Kujawsko-pomorski & 39915 & $99.45 \%$ & 689229.30 & 220 & $0.55 \%$ & 3600.00 & 40135 \\
\hline 3 & Lubelski & 41175 & $99.54 \%$ & 761898.20 & 189 & $0.46 \%$ & 3024.00 & 41364 \\
\hline 4 & Lubuski & 18606 & $100.00 \%$ & 303983.60 & 0 & $0.00 \%$ & 0.00 & 18606 \\
\hline 5 & Łódzki & 46339 & $99.85 \%$ & 775156.96 & 71 & $0.15 \%$ & 1136.00 & 46410 \\
\hline 6 & Małopolski & 58238 & $99.71 \%$ & 1060502.94 & 167 & $0.29 \%$ & 2688.00 & 58405 \\
\hline 7 & Mazowiecki & 78822 & $99.55 \%$ & 1429549.90 & 353 & $0.45 \%$ & 5696.00 & 79175 \\
\hline 8 & Opolski & 19605 & $99.69 \%$ & 372071.00 & 60 & $0.31 \%$ & 960.00 & 19665 \\
\hline 9 & Podkarpacki & 35752 & $99.84 \%$ & 613325.00 & 56 & $0.16 \%$ & 896.00 & 35808 \\
\hline 10 & Podlaski & 23741 & $99.83 \%$ & 419142.96 & 40 & $0.17 \%$ & 640.00 & 23781 \\
\hline 11 & Pomorski & 48619 & $98.35 \%$ & 814272.96 & 818 & $1.65 \%$ & 13120.00 & 49437 \\
\hline 12 & Śląski & 95772 & $99.69 \%$ & 1573446.80 & 300 & $0.31 \%$ & 4816.00 & 96072 \\
\hline 13 & Świętokrzyski & 21611 & $99.19 \%$ & 384404.70 & 176 & $0.81 \%$ & 2816.00 & 21787 \\
\hline 14 & Warmińsko-mazurski & 37685 & $99.80 \%$ & 685707.72 & 75 & $0.20 \%$ & 1200.00 & 37760 \\
\hline 15 & Wielkopolski & 40168 & $99.91 \%$ & 729894.04 & 37 & $0.09 \%$ & 592.00 & 40205 \\
\hline 16 & Zachodniopomorski & 41046 & $100.00 \%$ & 701549.12 & 0 & $0.00 \%$ & 0.00 & 41046 \\
\hline \multicolumn{2}{|c|}{ TOTAL } & 697157 & $99.58 \%$ & 12232291.3 & 2929 & $0.42 \%$ & 47072.00 & 700086 \\
\hline
\end{tabular}

Table 5. The number of midwives participating in the course on collecting pap smear tests within the prevention of cervical cancer program in the year 2014 broken down into voivodeships (source: Central Coordinating Centre for Cervical Cancer Prevention Program)

\begin{tabular}{|c|c|c|c|c|c|c|}
\hline \multirow{2}{*}{\multicolumn{2}{|c|}{ Provincial Coordinating Centre }} & \multicolumn{2}{|c|}{ SOC midwives } & \multicolumn{2}{|c|}{ PHC midwives } & \multirow{3}{*}{\begin{tabular}{|c|} 
TOTAL \\
33 \\
\end{tabular}} \\
\hline & & \multirow{2}{*}{$\begin{array}{c}\text { Number } \\
0\end{array}$} & \multirow{2}{*}{$\begin{array}{c}\% \\
0.00 \%\end{array}$} & \multirow{2}{*}{$\begin{array}{c}\% \text { Number } \\
33\end{array}$} & \multirow{2}{*}{$\begin{array}{c}\% \\
100.00 \%\end{array}$} & \\
\hline 1 & Dolnośląskie & & & & & \\
\hline 2 & Kujawsko-pomorskie & 12 & $23.08 \%$ & 40 & $76.92 \%$ & 52 \\
\hline 3 & Lubelskie & 46 & $34.59 \%$ & 87 & $65.41 \%$ & 133 \\
\hline 4 & Lubuskie & 0 & $0.00 \%$ & 0 & $0.00 \%$ & 0 \\
\hline 5 & Łódzkie & 0 & $0.00 \%$ & 0 & $0.00 \%$ & 0 \\
\hline 6 & Małopolskie & 27 & $71.05 \%$ & 11 & $28.95 \%$ & 38 \\
\hline 7 & Mazowieckie & 37 & $37.00 \%$ & 63 & $63.00 \%$ & 100 \\
\hline 8 & Opolskie & 3 & $10.34 \%$ & 26 & $89.66 \%$ & 29 \\
\hline 9 & Podkarpackie & 26 & $41.94 \%$ & 36 & $58.06 \%$ & 62 \\
\hline 10 & Podlaskie & 0 & $0.00 \%$ & 0 & $0.00 \%$ & 0 \\
\hline 11 & Pomorskie & 34 & $75.56 \%$ & 11 & $24.44 \%$ & 45 \\
\hline 12 & Śląskie & 42 & $56.00 \%$ & 33 & $44.00 \%$ & 75 \\
\hline 13 & Świętokrzyskie & 30 & $53.57 \%$ & 26 & $46.43 \%$ & 56 \\
\hline 14 & Warmińsko-mazurskie & 0 & $0.00 \%$ & 0 & $0.00 \%$ & 0 \\
\hline 15 & Wielkopolskie & 52 & $83.87 \%$ & 10 & $16.13 \%$ & 62 \\
\hline 16 & Zachodniopomorskie & 5 & $7.35 \%$ & 63 & $92.65 \%$ & 68 \\
\hline \multicolumn{2}{|c|}{ TOTAL } & 314 & $41.70 \%$ & 439 & $\mathbf{5 8 . 3 0} \%$ & 753 \\
\hline
\end{tabular}


2016. Despite the increase observed, PHC entities still constitute merely over $10 \%$ of all service providers who offer pap smear tests to the patients. Undoubtedly, these changes are positive but their rate, according to their authors, is highly disappointing and not resulting in the major growth of women's reportability for preventive examinations directed towards CC early detection on the national scale.

Both Barnaś et al. and Pasławska et al. indicate that young women inhabitating rural areas are the ones who rarely participate in the Program $[9,10]$. In the authors' opinion, the possibility of gathering pap smears by a PHC midwife raises a chance for the increasing patients' interest in the participation in the Program. Young women of a childbearing age, are usually the patients of PHC midwifes in the scope of prenatal education and check-up visits after the birth. Undoubtedly, this fact enables additional possibility for personal invitation to the Program, and also to provide health education in the range of early CC prevention. It should be noticed that PHC midwife carries out services in accordance with PHC clinic timetable i.e. from Monday to Friday from 8:00 am to 6:00 o'clock pm, which together with a short distance from the family practitioner clinic to the dwelling-place makes a significant facilitation in the field of benefiting from services [11]. The distance from the institution has a valid meaning in the case of rural areas, where PHC clinic is much easier available to patients, in comparison to obstetrical-gynecological clinic which carries out its services under SOC.

Additionally, in view of the Program basic stage new organizational solutions, a close cooperation of $\mathrm{PHC}$ midwife and PHC practitioner may be a helpful factor in reaching the potential participants of the Program. The initiators of changes, in their recommendations for 2012, pointed out to the undefined role of family practitioners', as compared to the solutions functioning in Belgium or Holland [7]. That situation is confirmed by CC prevention information sources [10]. In view of the above, family practitioners should be taught how to motivate patients to take part in the preventive programs, emphasizing, at the same time, the significance of the education of medical personnel in the framework of the preventive activities performed [12].

As it has been mentioned in the introduction, pap smear tests can be performed only by $\mathrm{PHC}$ midwives whose qualifications in this respect are confirmed by the COC exam. The data show bigger interest in the course organized by $\mathrm{COC}$ among $\mathrm{PHC}$ midwives in comparison to $\mathrm{SOC}$ midwives, however, this situation mostly results from the fact that these courses has been organized for the latter group for many years. However, it should be mentioned, it is not the necessity of rising qualifications that seems to be the main factor impairing the situation of PHC midwives, but economic matters connected with the indispensability of the proper equipment for medical practice, in which the largest cost is the purchase of a gynecological chair [5]. Such changes usually involve the decision of the person who is in charge of the health entity or general practice, and their initiation is directly associated with the financing level offered by NFZ under the contracts. At present, the service performed by $\mathrm{PHC}$ midwife, which is the collection of pap smear for screening, costs 17 PLN, while one cannot forget about funding the readiness to provide services based on the capitation rate of PLN 17.16 (PLN 19.56 since 01.09.2016), paid for every patient or an infant (both sexes) placed on PHC midwife's list based on "the declaration of choice" submitted by patients [13].

The increase in the effectiveness of activities carried out within the Program undoubtedly requires close cooperation in many areas, both among the service providers (PHC, SOC), public payer (NFZ), the Program's promoter (The Ministry of Health) and units constituting the back office and informational, educational background (COC, PCOCs). With reference to the last enumerated entities, the present situation must be mentioned (January-March 2016). On 31 December 2015 both COC and PCOCs finished their activity within the "National Cancer Control" for the years 2006-2015, which in the last two years was implemented on the basis of the Resolution of the Council of Ministers about the timetable of tasks performed in the framework of the multi-year national cancer control program in the years 2014 and 2015, created in accordance with Art. 5 Act of 1 July 2005 on the establishment of the multi-year national cancer control program $[14,15]$. The actual "National Cancer Control Program" for years 2016-2024 has not been legally normalized by the legal act, although it mentions the Ministry of Health as the implementer of the Program, but at the same time it does not impose any obligation to present work schedule within the Program. Furthermore, in the described legal Act, there is no mention of the possible establishment of new COC or PCOCs [16]. In the present situation (state of being at 27.04.2016) there is no legally normalized back office for the Population Program for the Early Detection of Cervical Cancer. What is more, in the legal act there is no foregoing name mentioned in the Program, but it only indicates the continuation of the existing activities within the V.1 (Health promotion and cancer prevention) and V.2 (Secondary prevention and cancer detection) priorities of "National Cancer Control Program". A few months delay in organizing the new CC prevention program has undoubtedly slowed down the introduction of any changes, the purpose of which was to increase the effectiveness of the activities performed.

\section{CONCLUSIONS}

The effective prevention of cancer involves multi-sector activities, however primary health care plays a very signifi- 
cant role in this respect, including mostly midwives cooperating closely with general practitioners.

Introduction of the legislative changes, allowing PHC midwives to collect pap smear for screening, did not cause, in the observation period (on a national scale), the expected growth of availability of the basic stage of cervical cancer prevention program.

Silesian voivodeship, in accordance with fast-growing health services market, realized by PHC midwives in the field of cervical cancer prevention, should be concerned as a pattern for other regions of the country.

Among the methods of actions efficiency, it is obligatory to consider a duty of cytological material sampling for screening by the facilities participating in the Program. In this respect, it is also important to define a role of general practitioners, in order to reduce the problem of fuzzy responsibility for the actions implementation.

\section{REFERENCES}

1. International Agency for Research on Cancer data (globocan.iarc.fr and eco.iarc.fr, accessed 04.02.2016).

2. Dane Krajowego Rejestru Nowotworów (onkologia.org.pl, accessed 04.02.2016).

3. Wojtyniak B, Goryński P, Moskalewicz B. Sytuacja zdrowotna ludności polski i jej uwarunkowania. Narodowy Instytut Zdrowia Publicznego - PZH, Warszawa 2012, p. 170.

4. Dane Wojewódzkiego Ośrodka Koordynującego Populacyjne Programy Wczesnego Wykrywania Raka Piersi oraz Profilaktyki i Wczesnego Wykrywania Raka Szyjki Macicy do 31.12.2015 r. (rakszyjki.org, accessed: 04.02.2016).

5. Rozporządzenie Ministra Zdrowia z dnia 6 listopada 2013 roku w sprawie świadczeń gwarantowanych z zakresu programów zdrowotnych, Dz.U. 2013 poz. 1505, (isap.sejm.gov.pl, accessed 04.02.2016).
6. Załącznik nr 4 do zarządzenia Nr 84/2014/DSOZ Prezesa Narodowego Funduszu Zdrowia z dnia 16 grudnia 2014 r. (nfz.gov.pl, accessed 04.02.2016).

7. Rekomendacje kompleksowych zmian w obszarze profilaktyki raka szyjki macicy w Polsce, Polska Koalicja na Rzecz Walki z Rakiem Szyjki Macicy, Warszawa 2012 (koalicjarsm.pl, accessed 04.02.2016).

8. Holecki T, Sobczyk K, Nawrocki S, Woźniak-Holecka J, Skrzypek M, Bocionek A. Koszty leczenia nowotworów złośliwych szyjki macicy w Polsce w latach 2011-2012 na przykładzie województwa śląskiego. Ginekol Pol. 2015, 85, 849-855.

9. Barnaś E, Borowiec-Domka E, Kądziołka J, Grzegorczyk J. Czynniki wpływające na zgłaszalność kobiet z Podkarpacia na badania cytologiczne w ramach Ogólnopolskiego Profilaktyki Raka Szyjki Macicy. Probl Hig Epidemiol. 2008, 89, 482-486.

10. Pasławska A, Mrożek-Budzyn D, Majewska R. Wiedza młodych kobiet na temat znaczenia badań cytologicznych w profilaktyce raka szyjki macicy. Probl Hig Epidemiol. 2014, 95, 170-174.

11. Zarządzenie Nr 77/2015/DSOZ Prezesa Narodowego Funduszu Zdrowia z dnia 19 listopada 2015 r. w sprawie określenia warunków zawierania i realizacji umów o udzielanie świadczeń opieki zdrowotnej w rodzaju: podstawowa opieka zdrowotna (nfz.gov.pl, accessed 04.02.2016).

12. Spaczyński M, Nowak-Markwitz E, Januszek-Michalecka L, Karowicz-Bilińska A. Profil socjalny kobiet a ich udział w Programie Profilaktyki i Wczesnego Wykrywania Raka Szyjki Macicy w Polsce. Ginekol Pol. 2009, 80, 833-838.

13. Załączniknr 1 do zarządzenia Nr 77/2015/DSOZ Prezesa Narodowego Funduszu Zdrowia z dnia 19 listopada 2015 r. (nfz.gov.pl, accessed 04.02.2016).

14. Uchwała nr 95/2014 Rady Ministrów z dnia 28 maja 2014 r. w sprawie w sprawie harmonogramu zadań wykonywanych w ramach programu wieloletniego „Narodowy program zwalczania chorób nowotworowych" w roku 2014 i 2015 (mz.gov.pl, accessed 22.03.2016).

15. Ustawa $z$ dnia 1 lipca 2005 r. o ustanowieniu programu wieloletniego "Narodowy program zwalczania chorób nowotworowych", Dz.U. z 2005 r. $\mathrm{Nr}$ 143, poz. 1200, z 2008 r. Nr 54, poz. 325 (isap.sejm.gov.pl, accessed 22.03.2016).

16. Uchwała nr 208 Rady Ministrów z dnia 3 listopada 2015 r. w sprawie ustanowienia programu wieloletniego na lata 2016-2024 pod nazwą "Narodowy Program Zwalczania Chorób Nowotworowych" (mz.gov.pl, accessed 22.03.2016).

17. Dane Narodowego Funduszu Zdrowia dotyczące zawieranych ze świadczeniodawcami umów o realizację świadczeń opieki zdrowotnej (aplikacje.nfz.gov.pl; accessed: 19.03.2016). 